\title{
Dobra praktyka w zarządzaniu szkołą wyższą - system ewaluacji jakości kształcenia na przykładzie uniwersytetów brytyjskich
}

\begin{abstract}
The aim of the article is to overview the methods and procedures of the higher education's quality evaluation system applied at English universities, as well as drawing conclusions referring to the applicability of these experiences in Polish circumstances. The exemplary universities, i.e. the University of Bolton, near Manchester and the University of Hertfordshire in Hatfield, not far from London conduct an internal evaluation, employing their own methods, and, additionally, participate in an external evaluation, both national and international. The latter is carried out by special institutions, such as: The Higher Education Academy, Ipsos MORI - a company using the National Student Questionnaire (NSS), The Quality Assurance Agency for Higher Education and The International Graduate Insight Group (i-graduate) that belonging to The Tribal Group PLC. The topics covered involve: the importance of the quality of teaching evaluation in the process of university management, procedures and methods for the assessment of the didactics' quality applied in England (using the examples of two above-mentioned universities) as well as some conclusions concerning
\end{abstract}

1 Tadeusz Marian Ostrowski, Instytut Psychologii Stosowanej, Wydział Zarządzania i Komunikacji Społecznej, Uniwersytet Jagielloński, Polska, tadeusz.ostrowski@uj.edu.pl. 
the applicability of British experiences in Polish educational environment including potential benefits and difficulties.

\section{Keywords:}

university didactics, education quality's evaluation, university management, Bolton, Hertfordshire

\section{WPROWADZENIE}

Jednym z ważnych obszarów zarządzania uczelnią wyższą jest dydaktyka, w tym sprawna ewaluacja jej efektów. Ocena rezultatów działania wszelkiego typu instytucji oraz inicjatyw społecznych weszła w naszych czasach do kanonu kultury organizacji, co wiąże się z przejściem z gospodarki zarządzanej centralnie do wolnorynkowej. Zasady konkurencji wymuszają badanie jakości usług i produktów, a to służy następnie budowaniu czy też potwierdzaniu prestiżu instytucji, w tym uczelni wyższych. Słuszną zasadą jest usprawnianie elementów złożonego procesu zarządzania uczelnią poprzez poznawanie rozwiązań stosowanych za granicą. Celem artykułu jest przedstawienie procedury badania jakości dydaktyki stosowanej w uniwersytetach brytyjskich oraz odniesienie wniosków z tego przeglądu do realiów polskich.

Dydaktyka uniwersytetów w Wielkiej Brytanii podlega podwójnej ewaluacji. Z jednej strony ankietową, elektroniczną ocenę swej dydaktyki przeprowadzają uniwersytety z własnej inicjatywy i dla swoich potrzeb, ale równocześnie każdy z nich jest oceniany przez zewnętrzną, niezależną instytucję. System ewaluacji dydaktyki zostanie omówiony z jednej strony na przykładzie dwu uniwersytetów, a mianowicie: Uniwersytetu w Bolton koło Manchesteru oraz Uniwersytetu Hertfordshire w Hatfield, leżącego około 46 km na północ od Londynu. Z drugiej strony jako przykład posłużą instytucje krajowe oraz międzynarodowe, z usług których korzystają angielskie uniwersytety, a mianowicie: brytyjska Akademia Szkolnictwa Wyższego (The Higher Education Academy), następnie Ipsos MORI - firma, która prowadzi badania za pomocą Narodowego Kwestionariusza Studenckiego (National Student Survey NSS), idąc dalej: Agencja Zapewnienia Jakości Szkolnictwa Wyższego (Quality Assurance Agency for Higher Education) i wreszcie The International Graduate Insight Group (i-graduate), która należy do The Tribal Group PLC. 


\section{ZNACZENIE OCENY JAKOŚCI DYDAKTYKI W PROCESIE ZARZĄDZANIA UCZELNIĄ WYŻSZĄ}

Ewaluacja jakości kształcenia jest ważnym ogniwem procesu monitorowania i ciągłego udoskonalania procesu dydaktycznego. Podkreślają to zarówno Uniwersytet w Bolton ${ }^{2}$, jak i Uniwersytet Hertfordshire ${ }^{3}$ w swoich podstawowych dokumentach, jakimi są strategie rozwoju uniwersytetu.

Wśród priorytetów wynikających z misji Uniwersytetu w Bolton w Strategii Rozwoju na lata 2016-2020 na pierwszym miejscu figuruje „doświadczenie i satysfakcja studentów”. Na liście priorytetów uwzględniono też: „zapewnienie efektywnych procedur badania jakości dydaktyki” (University of Bolton. Strategic Plan 2016-2020, s. 4).

Znaczenie dydaktyki podkreślone jest również w dokumentach Uniwersytetu Hertfordshire. Strategia rozwoju Uniwersytetu Hertfordshire na lata 2016-2020 zawiera podstawową wizję: „Zyskamy międzynarodową sławę, jako wiodący w Wielkiej Brytanii uniwersytet, ukierunkowany frontem do biznesu”. Pierwszym kluczowym celem rozwoju jest: „zapewnienie wysokiego poziomu nauczania przez fachowców naukowych, biznesowych i zawodowych” (University of Hertfordshire. Strategic Plan 2016-2020, s. 4) ${ }^{5}$. Ambicją Uniwersytetu jest zadbać o pozytywne doświadczenia swoich studentów (Student Experience

2 Uniwersytet w Bolton liczy około 10 tysięcy studentów.

3 Uniwersytet Hertfordshire ma około 30 tysięcy studentów.

4 Uniwersytet w Bolton wymienia siedem głównych priorytetów rozwoju, a mianowicie: „1. Doświadczenie i satysfakcja studentów. 2. Skupienie się na intensywnie wspieranym nauczaniu (chodzi o tutoring) i rozwoju środowiska uczenia się. 3. Inwestowanie w kadrę - rozwój obecnie zatrudnionych pracowników, jak również zatrudnianie nowych. 4. Inwestowanie w infrastrukturę IT (technologia informatyczna). 5. Solidna i dobrze rozwinięta strategia komunikacji. 6. Solidne planowanie cyklu dydaktycznego: projektowanie, wdrożenie i monitorowanie. 7. Lokalne planowanie, oparte na głównym planie strategicznym. 8. Zapewnienie efektywnych procedur badania jakości dydaktyki” (University of Bolton. Strategic Plan 2016-2020, s. 4, tłum. własne).

5 Uniwersytet Hertfordshire formułuje kluczowe cele strategiczne, poprzedzając je ogólną wizją rozwoju: „Zyskamy międzynarodową sławę jako wiodący w Wielkiej Brytanii uniwersytet, ukierunkowany frontem do biznesu, poprzez: zapewnienie wysokiego poziomu nauczania przez fachowców naukowych, biznesowych i zawodowych; oferowanie możliwości znalezienia pracy i kształcenia za granicą; tworzenie i rozwój innowacyjnych pomysłów, produktów i procesów; rozwój partnerstwa międzynarodowego; wzmocnienie globalnej perspektywy w programie nauczania; rozwój studentów w zakresie wiedzy, umiejętności i postaw, ukierunkowany na sukces w biznesie i w zawodzie; pogłębianie relacji z biznesem i przemysłem; wykazywanie i promowanie pozytywnego wpływu uczelni w wymiarze społecznym, kulturalnym i gospodarczym; przyciągnięcie i rozwój wybitnych osób; zwiększenie różnorodności naszej społeczności; skonsolidowanie zrównoważonego rozwoju finansowego" (University of Hertfordshire. Strategic Plan 2016-2020, s. 4, tłum. własne). 
Strategy 2010-2015) w takim stopniu, aby w wyniku zewnętrznej ewaluacji, za pomocą Narodowego Kwestionariusza Studenckiego (National Student Survey) Uniwersytet uzyskał jak najwyższą rangę wśród uczelni wyższych w Wielkiej Brytanii. Ujawnia się tu znaczenie instytucji, które stanowią obok uniwersytetów drugi podstawowy przedmiot tego artykułu, to znaczy organizacji dokonujących ewaluacji akademickiej dydaktyki z zewnątrz, niezależnie od uczelni.

Wśród uniwersytetów brytyjskich powszechne jest korzystanie z usług Ipsos MORI - firmy, która przedstawia się jako największa instytucja badania rynku w Wielkiej Brytanii. Jest ona wykonawcą badań marketingowych dotyczących uczelni wyższych, którre prowadzi za pomocą wspomnianego Narodowego Kwestionariusza Studenckiego. Celem są badania porównawcze brytyjskich wyższych uczelni w zakresie satysfakcji ze studiowania na studiach pierwszego stopnia, prowadzone od roku 2005 w czterech krajach Wielkiej Brytanii, to znaczy w Anglii, Walii, Północnej Irlandii oraz w Szkocji. Wyniki badań adresowane są do kandydatów na wyższe uczelnie oraz ich rodzin, jako obiektywne kryterium wyboru uczelni i kierunku.

Ewaluacją procesu dydaktycznego w Wielkiej Brytanii zajmuje się również Akademia Szkolnictwa Wyższego (The Higher Education Academy), która pełni rolę koordynatora działania uczelni wyższych, w każdym wymiarze, to znaczy powstawania zespołów badawczych, międzyuczelnianych, pozyskiwania funduszy na badania, kształtowania polityki oświatowej i badań naukowych w kraju. Ważnym wymiarem działania Akademii jest ewaluacja jakości dydaktyki. Celem ewaluacji jest wskazanie najlepszych ośrodków w Wielkiej Brytanii oraz inspirowanie kierunku zmian i dalszego rozwoju uczelni. O członkostwo w Akademii mogą ubiegać się pracownicy wyższych uczelni. Akademia przyznaje członkostwo na czterech poziomach uczestnictwa, a także coroczne nagrody za wysoką jakość nauczania.

W państwach o wieloletnich tradycjach w zakresie gospodarki wolnorynkowej zawsze przywiązywano dużą wagę do ewaluacji jakości, co w wymiarze szkolnictwa wyższego przekłada się na funkcjonowanie szeregu instytucji kompetentnych w tym zakresie. Systematyczne badanie jakości dydaktyki szkolnictwa wyższego w całym Zjednoczonym Królestwie prowadzi również Agencja Jakości Szkolnictwa Wyższego (Quality Assurance Agency for Higher Education), która przedstawia się, jako „niezależne ciało, któremu powierzono monitorowanie i doradztwo w zakresie standardów i jakości w szkolnictwie wyższym w UK” (Quality Assurance Agency..., s. 3, tłum. własne). Agencja współpracuje z podobnymi instytucjami w Europie, na forum The European Association for Quality Assurance in Higher Education oraz na świecie, w ramach The International Network for 
Quality Assurance Agencies in Higher Education. Swoją misję Agencja określa w sposób charakterystyczny dla współczesnej Unii, nawiązujący do deklaracji bolońskiej, to znaczy poprzez określenie wiodących wartości, a mianowicie: integralność (interpretowana, jako obiektywizm i uczciwość), profesjonalizm, odpowiedzialność, otwartość i niezależność ${ }^{6}$. W swojej działalności, w zakresie od szczebla ministerialnego do najmniejszych uczelni, Agencja opiera się na wynikach badań ankietowych prowadzonych wśród studentów. Rezultaty badań służą nie tylko określeniu miejsca konkretnej uczelni w hierarchii badanych placówek, ale także sformułowaniu szeregu postulatów, których celem jest podwyższanie jakości usług dydaktycznych.

Zewnętrzna ewaluacja jakości dydaktyki ma zakres krajowy i międzynarodowy. W tym drugim obszarze działa instytucja międzynarodowa, jaką jest The International Graduate Insight Group (i-graduate). Prowadzi ona badania jakości usług dydaktycznych 1400 instytucji na każdym poziomie szkolnictwa o profilu międzynarodowym. W przypadku szkół niższego szczebla badanie dotyczy opinii i oczekiwań rodziców, natomiast w szkołach średnich i uniwersytetach ewaluacja obejmuje opinie uczniów i studentów w zakresie jakości wszystkich wymiarów życia szkolnego w 30 krajach, w tym w uniwersytetach brytyjskich, a także w krajach Unii Europejskiej oraz na wszystkich kontynentach w uczelniach, które są abonamentami usług firmy The Tribal Group PLC ${ }^{7}$, z grupy The International Graduate Insight Group (i-graduate). Celem tej ewaluacji jest stworzenie międzynarodowej płaszczyzny porównania wyższych uczelni pod względem jakości dydaktyki oraz innych wymiarów życia studentów. Wyniki ewaluacji są prezentowane w wydawnictwie ciągłym - zatytułowanym podobnie jak ankieta - Międzynarodowy Barometr Studencki (The International Student Barometer, ISB).

6 Dla porównania większość uczelni polskich opiera badanie jakości dydaktyki na dwu zasadach: anonimowość i dowolność.

7 The Tribal Group PLC jest międzynarodową instytucją, specjalizującą się w budowaniu systemów komputerowych dla szeroko rozumianej oświaty, szkoleń i dydaktyki. W związku z tym klientami firmy są szkoły wyższe, ośrodki służby zdrowia, ale także władze krajowe i lokalne. Zakresem usług instytucja ta obejmuje głównie Europę, USA i Kanadę, Australię i Bliski Wschód. 


\section{PROCEDURY I METODY BADANIA JAKOŚCI DYDAKTYKI STOSOWANE W WIELKIEJ BRYTANII NA PRZYKŁADZIE DWÓCH WYBRANYCH UNIWERSYTETÓW}

Uniwersytet w Bolton stosuje dwa własne kwestionariusze: metodę do oceny modułu studiowania, a mianowicie Kwestionariusz Modułu w Szkole...8 (School of <???>: Module Questionnaire). Druga metoda to Kwestionariusz Satysfakcji Studenta Uniwersytetu (University Student Satisfaction Survey), dotyczący ewaluacji na poziomie kursów, czyli programu, jaki deklaruje student.

Kwestionariusz Modułu w Szkole... (School of <???>: Module Questionnaire) przeznaczony jest dla wszystkich studentów. Zawiera on twierdzenia dotyczące oceny pojedynczego modułu prowadzonego przez jedną osobę lub niewielkie grono osób, a więc siłą rzeczy mówi trochę więcej o indywidualnym nauczycielu akademickim niż druga z wymienionych metod, która już wyraźnie odnosi się do zespołu realizującego wybrany kurs. Warto jednak zwrócić uwagę, że 23 pozycje Kwestionariusza Modułu dotyczą jednak zdecydowanie bardziej modułu, niż prowadzącego. Chodzi głównie o opinię studenta o organizacji modułu, dostępności źródeł wiedzy, adekwatności oceny, pomocy ze strony opiekuna (tutora), którego zadaniem jest służenie radą studentowi w niełatwym procesie wybierania modułów ${ }^{9}$. Nie ma natomiast twierdzeń odnoszących się do kompetencji nauczyciela akademickiego, a zwłaszcza do poziomu przygotowania się na zajęcia, jakie zdarzają się w ankietach w naszych uniwersytetach. W Anglii jest oczywiste, że zajęcia są dobrze przygotowane i pytanie o to jest nieracjonalne i nietaktowne. Poza tym z rozmów i z analizy dokumentów odnieść można wrażenie, że na uczelni panuje klimat uznania dla nauczyciela akademickiego. Można sądzić, że Brytyjczycy strzegą autorytetu nauczyciela, znając jego wartość wychowawczą. I nie dzieje się to z niczyjego nakazu. Po prostu jest to znamienne, jako cecha kultury organizacji ${ }^{10}$, i naturalne zarówno wśród kadry, jak i pracowników administracji, którzy z szacunkiem zwracają się do nauczycieli akademickich.

8 W organizacji dydaktyki Uniwersytetu w Bolton wyróżnia się sześć grup przedmiotów (Sześć szkół): Art, Design and Language; Business, Accountancy and Law; Creative Technologies; Education and Psychology; Engineering, Sports and Sciences; Health and Community Studies.

9 Moduły mają określoną ilość miejsc i są wkomponowane w harmonogram. Tutor pomaga ułożyć indywidualny harmonogram zajęć studenta.

10 Kulturę organizacji dużo trudniej odbudować niż kulturę materialną. Dlatego każdy okupant przede wszystkim wyniszcza inteligencję, wiedząc, że jest to ta warstwa społeczna, która w zakresie szkolnictwa przekazuje pokoleniowo kulturę organizacji. Wydaje się, że zniszczenia dokonane przez okupantów w tym zakresie w czasie II wojny światowej po dzień dzisiejszy nie zostały usunięte. 
Druga metoda opracowana przez Uniwersytet w Bolton - Kwestionariusz Satysfakcji Studenta Uniwersytetu (University Student Satisfaction Survey), jest przeznaczona dla studentów studiów licencjackich i dotyczy ewaluacji jakości dydaktyki w zakresie całego programu studiów. Kwestionariusz zawiera pytania dotyczące zespołu uczącego, adekwatności oceny efektów studiowania, wsparcia, jakie otrzymuje student w każdym wymiarze, to znaczy w zakresie organizacji kursów, komunikacji z prowadzącym, dostępności biblioteki, ale także poczucia rozwoju osobistego i umiejętności zawodowych. Kwestionariusz stwarza możliwość wpisania własnych komentarzy przez studenta.

Sposób administrowania kwestionariuszami z pozoru nie odbiega od standardu. Każdy student jest zachęcany drogą e-mailową do wyrażania swej opinii, którą wysyła w systemie elektronicznym. Badanie ma charakter anonimowy. Jednakże system identyfikuje respondenta za pomocą identyfikatora URL ${ }^{11}$. Identyfikacja jest konieczna, ponieważ wysyłane są monity do studentów, którzy nie odpowiedzieli na ankietę. Studenci mają więc świadomość, że system w jakiś sposób ich rejestruje, a pomimo to ${ }^{12}$ stopień zwrotu kwestionariuszy kształtuje się na poziomie około 30\%, co w Wielkiej Brytanii uważa się za dobry poziom frekwencji w komputerowych badaniach opinii publicznej, zwłaszcza w większych grupach, to znaczy powyżej stu respondentów. Wydaje się, że kluczowym momentem w tego rodzaju anonimowym ankietowaniu z zachowaniem kontroli odpowiedzi jest fakt, że w tej procedurze „system” ma twarz, imię i nazwisko znane studentom. Jest to pracownik Uniwersytetu, który w instrukcji dla studentów występuje jako jedyna osoba mająca dostęp do URL ich odpowiedzi ${ }^{13}$. Do niej należy monitorowanie przebiegu ankietowania. Trudno oprzeć się wrażeniu, że ważnym, jeśli

11 URL (ang. Uniform Resource Locator), skrót oznaczający w przybliżeniu adres określonych materiałów w sieci wraz z informacją, w jaki sposób można do nich dotrzeć. URL jest skrótem powszechnie stosowanym na świecie i nie ma polskiego odpowiednika. Można zaproponować: Sieciowy Identyfikator Zasobów - SIZ.

12 „Pomimo to”, ponieważ anonimowość uważa się w Polsce za warunek uzyskania stopnia zwrotu na przyzwoitym poziomie. Z zachowaniem pełnej anonimowości stopień zwrotu utrzymujący się od szeregu lat w wielu polskich uczelniach oscyluje wokół 30\%, to znaczy nie przekracza średniej w Anglii, gdzie anonimowość jest kontrolowana. Okazuje się, że systemowa identyfikacja respondentów nie wpływa znacząco na obniżenie liczby odpowiedzi.

13 Ponieważ sposób ochrony danych osobowych studentów uczestniczących w badaniach jakości dydaktyki Uniwersytetu w Bolton jest kluczowy w tym fragmencie artykułu, warto zapoznać się z odnośnym fragmentem instrukcji dla studentów w Kwestionariuszu Satysfakcji Studenta Uniwersytetu (University Student Satisfaction Survey). W oryginale brzmi on następująco: „Data Protection. All data collected in this survey will be held securely. The University will not identify any individuals when reporting the results, and will use our the best efforts to ensure that no individuals can be identified by implication so your results are anonymous. Your survey URL details will be 
nie kluczowym momentem w całej akcji badania opinii studentów jest poczucie bezpieczeństwa, oparte na zaufaniu do konkretnej osoby, z którą studenci mogą się zidentyfikować ${ }^{14}$ i do której można się zwrócić w razie jakichkolwiek wątpliwości. Relacja bezosobowa: student - system, jest w tym wypadku zastąpiona relacją osobową: student - pracownik uczelni.

Jeśli chodzi o treść kwestionariusza, warto zwrócić uwagę na fakt, że zawiera on pytania dotyczące zespołu prowadzącego kurs, a nie indywidualnego prowadzącego.

Niezależnie od własnych badań, Uniwersytet w Bolton, jako jedna z ponad stu brytyjskich uczelni, korzysta z zewnętrznej ewaluacji zajęć, prowadzonej przez Akademię Szkolnictwa Wyższego, o której wspomniano we wstępie. Używane są dwie metody, obydwie oceniające program studiów, a nie pojedynczy moduł. Jedną z nich jest Postgraduate Taught Experience Survey - PTES, adresowany do studentów o profilu zawodowym, którzy zamierzają uzyskać zawodowy stopień magistra (Taught Master). W praktyce obejmuje wszystkich studentów drugiego stopnia kształcenia - to znaczy na studiach magisterskich, tym bardziej, że w części C badany ma możliwość wypowiedzenia się na temat projektu i promotora pracy magisterskiej, a więc nie chodzi wyłącznie o studia zawodowe, w ramach których student z założenia nie przeprowadza badań.

W swej treści kwestionariusz w dużym stopniu przypomina wcześniej omówione metody, włącznie z konsekwentnie stosowanym, znamiennym sformułowaniem: „Czy zespół uczący jest nastawiony entuzjastycznie do nauczanego przedmiotu?”. Wyraźne jest tu wskazanie, że znajomość przedmiotu, właściwe przygotowanie to za mało. Dobry nauczyciel powinien być entuzjastą swojego przedmiotu. Przy czym znowu, tak jak poprzednio, metoda dotyczy zespołu, a nie osoby prowadzącego, tym bardziej, że chodzi o doświadczenia z realizacji całego programu.

Badanie opinii studentów prowadzone jest corocznie przez Akademię. W procedurze administrowania kwestionariuszem ujawnia się istotna właściwość zewnętrznej ewaluacji jakości dydaktyki - badania nie są anonimowe. Wypełnione formularze adresowane są do Akademii, która dysponuje bazą danych o respondentach, natomiast wyniki, bez danych personalnych, przekazuje współpracującym uniwersytetom. W przypadku studentów z Bolton liczba odpowiedzi utrzymuje się na poziomie ponad 30\%.

retained throughout the live survey period. This only person who will have access to this information is Bethany Humphreys, Student Data Management”.

14 Identyfikację studentów z Uniwersytetem ułatwia fakt, że osoba wymieniona w instrukcji na zdjęciu wygląda jak studentka wyższego roku. 
Postgraduate Research Experience Survey - PRES to druga metoda stosowana w Bolton, administrowana przez Akademię Szkolnictwa Wyższego. Kwestionariusz adresowany jest tym razem do studentów o profilu naukowym, a w praktyce do doktorantów, jakkolwiek profil taki mogą mieć również studia magisterskie, uwieńczone tytułem master in research. Badania prowadzone są co dwa lata. Ankieta dotyczy głównie oceny warunków realizowania projektu badań, dostępności zasobów wiedzy oraz tym razem już bardzo konkretnie kompetencji promotora. W odniesieniu do doktoranta nacisk położony jest przede wszystkim na ocenę rozwoju umiejętności pracy naukowej bardziej niż na zdobywanie nowej wiedzy. Procedura badania jest taka sama, jak w przypadku poprzednio omówionej metody. Liczba odpowiedzi kształtuje się w granicach $50 \%$.

Uniwersytet w Bolton korzysta także z Narodowego Kwestionariusza Studenckiego (National Student Survey NSS), który ma również zasięg ogólnokrajowy. Metoda zawiera 22 stwierdzenia, podzielone na sześć sekcji: a) Uczenie w ramach kursu (Cztery pytania o zespół prowadzący: „Czy zespół dobrze wyjaśnia przedmiot?”, „Czy zespół uczynił przedmiot interesującym?”, powtarzające się pytanie - „Czy zespół jest nastawiony entuzjastycznie do swojego przedmiotu? oraz „Czy kurs jest intelektualnie pobudzający?”), b) Ocena i informacje zwrotne, c) Wsparcie ze strony uczelni (Dostępność opiekuna i kadry), d) Organizacja kursu i zarządzanie, e) Dostępność źródeł wiedzy oraz f) Rozwój osobisty. Całości dopełnia pozycja dotycząca „satysfakcji ogólnej”. Jak widać w tym wypadku, ocena zajęć dotyczy nie pojedynczego modułu, a całego kursu, czyli w praktyce indywidualnego programu studenta końcowego roku studiów pierwszego stopnia. Dodatkowo umieszczono pytanie o opinię na temat organizacji studenckiej, w której uczestniczy respondent. Ma on również możliwość uzupełnienia oceny ilościowej za pomocą komentarzy.

Badanie przeprowadza i wyniki analizuje firma Ipsos-MORI, stosując podwójny próg wiarygodności oceny, a mianowicie 50\% odpowiedzi oraz liczbę co najmniej 23 odpowiadających studentów. Uniwersytet otrzymuje raport zawierający wyniki analizy, w których na wykresach określone jest jego miejsce w stosunku do średnich wyników wszystkich instytucji szkolnictwa wyższego uczestniczących w ocenie oraz w stosunku do 25\% najlepszych (górny kwartyl). Osobne tabele pozwalają określić wyniki oceny dydaktyki w poszczególnych jednostkach Uniwersytetu. Wyniki analizy są dyskutowane i sfinalizowane zaleceniami dotyczącymi działań, w kierunku poprawy jakości dydaktyki w poszczególnych jednostkach, dlatego raport jest poufny, przeznaczony dla władz uczelni. Osobną kategorią jest analiza komentarzy, z podziałem na pozytywne i negatywne. Autorzy opracowania zwracają uwagę na fakt, że największa ilość komentarzy 
w obydwu kierunkach dotyczy wsparcia ze strony zespołu nauczającego oraz jakości nauczania.

Druga z wymienionych powyżej uczelni - Uniwersytet Hertfordshire, podobnie jak Bolton, stosuje swoje własne metody oraz badania jakości dydaktyki krajowe i międzynarodowe. Do pierwszej kategorii należy metoda o nazwie Studencki Punkt Widzenia (Student Viewpoint SVP), natomiast narzędzia ewaluacji zewnętrznej to: Barometr Studencki (Student Barometer) oraz Narodowy Kwestionariusz Studencki (National Student Survey NSS), przy czym na osiem pozycji SVP dotyczących modułów, sześć powtarza się w NSS.

Studencki Punkt Widzenia to metoda badania jakości dydaktyki na poziomie modułu. Ankieta zawiera dwie części. Pierwsza składa się z ośmiu twierdzeń dotyczących oceny modułu: jego efektywności, organizacji, dostępności źródeł wiedzy, w tym e-learningu, dostępności zespołu, prowadzącego zajęcia, zrozumiałości informacji zwrotnej od prowadzących oraz stopnia, w jakim moduł stymuluje intelektualnie. Trzy końcowe pytania metody dotyczą nauczyciela akademickiego prowadzącego moduł, a mianowicie jak dalece prowadzący wykazał się umiejętnością wyjaśniania studiowanego przedmiotu, czy przedmiot był interesujący w przekazie prowadzącego oraz znowu powtarzające się pytanie - czy prowadzący jest entuzjastą swojego przedmiotu?

Z kwestionariuszem Studencki Punkt Widzenia treściowo koresponduje Narodowy Kwestionariusz Studencki, omówiony przy okazji metod stosowanych w Bolton.

Jeszcze szerszy, bo międzynarodowy, jest zasięg badania jakości dydaktyki prowadzonego przez The International Graduate Insight Group (i-graduate) za pomocą metody Międzynarodowy Barometr Studencki (The International Student Barometer). Firma przygotowała rozległy, składający się z ponad siedemdziesięciu pozycji, częściowo-standaryzowany kwestionariusz, obejmujący wszystkie dziedziny życia studenckiego. Wzorzec przesłany jest do każdego ze współpracujących uniwersytetów celem uzupełnienia pod kątem specyfiki uczelni. Następnie, za pomocą gotowej metody, instytucja przeprowadza badanie wśród studentów danego uniwersytetu, w okresie od października do grudnia (Autumn Wave), gromadząc i analizując wyniki. Zachętą dla studentów do aktywności w badaniach są informacje o zachowaniu tajności danych personalnych, o przydatności studenckiej oceny do rozwoju uczelni wyższych na świecie i budowania ich rankingu ${ }^{15}$ oraz perspektywa udziału w losowaniu nagrody w wysokości 1000 funtów.

15 W publikacji International Student Barometer 2016 autorzy podkreślają, że kwestionariusz wypełnia około 2,5 mln studentów, z 1400 instytucji, z 32 krajów. 
Międzynarodowy charakter badania ujawnia się między innymi w dużej liczbie stwierdzeń dotyczących przesłanek wyboru kraju i uczelni, procesu uzyskania wizy oraz przebiegu aplikacji na studia i źródeł finansowania. Poruszona jest także kwestia odczuć studenta pierwszego roku po przybyciu na wybraną uczelnię, z takimi szczegółami, jak odebranie z lotniska lub dworca i zapewnienie noclegu na pierwszą noc. W części dotyczącej studiowania pojawiają się ogólne pytania dotyczące zespołu nauczającego, a mianowicie o jakość wykładowców, ich znajomość nauczanej dziedziny, dostępność i kompetencje językowe. Wiele pozycji dotyczy warunków studiowania, lokalowych, aparaturowych, komputerowych, a także łatwości dotarcia do źródeł wiedzy. Ocenie podlega także poziom wsparcia ze strony opiekunów oraz organizacji studenckich. Osobny dział pytań dotyczy kwestii bytowych. Na zakończenie respondent proszony jest o podanie imienia, nazwiska, adresu e-mailowego oraz danych demograficznych, takich jak grupa etniczna, religia, wiek i płeć. Jak więc widać, kwestionariusz nie jest anonimowy. Ważną konkluzją całego badania są odpowiedzi studenta, dotyczące stopnia w jakim rekomenduje swoją uczelnię jej przyszłym kandydatom.

Każda uczelnia uczestnicząca w badaniu otrzymuje raport w formie wydawnictwa ciągłego: The International Student Barometer, w którym omówione są wyniki dotyczące uczelni w porównaniu z rezultatami w kraju i na świecie. Porównania obejmują rok prowadzenia badań i poprzedni. Analiza wyników dotyczy wszystkich badanych obszarów życia studenckiego. Do szczególnie eksponowanych punktów analizy należą: stopień rekomendacji określonej uczelni, adekwatność opłat, proporcja nakładu czasu i oczekiwań do wartości kształcenia, przesłanki decyzji o wyborze uczelni, ocena procesu aplikacji do uczelni, obszar zmian, oczekiwanych w związku z podniesieniem czesnego na uniwersytetach brytyjskich od roku 2012, doświadczenia po przybyciu na uczelnię, satysfakcja związana ze studiowaniem, warunkami bytowymi, wsparciem ze strony opiekunów oraz organizacji studenckich. Możliwe jest też dokładne zapoznanie się z wynikami badania w pozostałych krajach i z porównaniami międzynarodowymi. Na podstawie tych danych władze uczelni mogą podjąć strategiczne decyzje, dotyczące naboru, wysokości czesnego, wielkości stypendiów. Możliwe jest też dotarcie za pomocą hasła do bazy danych określonej uczelni, jednakże bez możliwości identyfikacji respondentów.

Dokonany przegląd metod i procedur badania jakości pozwala sformułować sugestie dotyczące możliwości ich zastosowania na gruncie polskim. 


\section{MOŻLIWOŚCI ZASTOSOWANIA BRYTYJSKICH PROCEDUR BADANIA JAKOŚCI DYDAKTYKI W UCZENIACH POLSKICH}

W zakresie metod i procedur wewnątrzuczelnianej oceny jakości dydaktyki podstawowe sugestie, nasuwające się po zapoznaniu się z praktyką Uniwersytetu Bolton i Hertfordshire, dotyczą treści pytań kwestionariusza oceny. Sformułowanie wniosków w tym zakresie jest istotne dla każdej uczelni, ponieważ trafność i rzetelność narzędzia jest kluczową sprawą ewaluacji. Ankiety ewaluacji przygotowywane są przez odpowiednie zespoły, powołane w poszczególnych jednostkach. Przykładowo, w Uniwersytecie Jagiellońskim wykonuje to Sekcja Analiz Jakości Kształcenia, która opracowuje narzędzia oceny jakości kształcenia, prowadząc wielostopniową zewnątrzuczelnianą i wewnątrzuczelnianą konsultację, przy współpracy z Uniwersyteckim Zespołem Doskonalenia Jakości Kształcenia oraz pełnomocnikami rektora i dziekanów (Przewodnik po działaniach projakościowych..., 2015).

Analizę treści pozycji szeregu omówionych kwestionariuszy można podsumować stwierdzeniem, że dotyczą one zdecydowanie bardziej oceny zajęć dydaktycznych niż nauczyciela akademickiego, a jeśli już twierdzenie dotyczy prowadzącego zajęcia, sformułowane jest w sposób bardzo wyważony i nienarażający nawet w najmniejszym stopniu autorytetu nauczyciela. Za niewłaściwe z tego punktu widzenia uznano by w Anglii pytanie, stosowane w polskich uczelniach, o to, czy prowadzący był przygotowany do zajęć. Właściwsze pod tym względem jest pytanie stosowane w ankiecie UJ, dotyczące tego, czy w wyniku zajęć wzrosła wiedza studenta. Z kolei w kontekście kwestionariuszy brytyjskich można rozważyć wprowadzenie pytania, które powtarza się prawie we wszystkich omówionych metodach, a mianowicie: „Czy Prowadzący przedstawia swój przedmiot z entuzjazmem?”.

Kolejnym problemem ewaluacji jakości dydaktyki, także uwarunkowanym etycznie, jest poruszana wielokrotnie w opracowaniu kwestia anonimowości versus jawności odpowiedzi studentów na pytania kwestionariusza. W tej sprawie ujawniają się co najmniej dwa sprzeczne stanowiska. Zgodnie z poglądem dominującym w Polsce w razie zrezygnowania z anonimowości spadnie drastycznie frekwencja odpowiadających na ankietę, a już w tej chwili procent odpowiedzi jest zazwyczaj niski. Co więcej, studenci, będący w zależności akademickiej od prowadzących, nie ujawnią opinii negatywnych, co doprowadzi do poważnych artefaktów i spowoduje zakwestionowanie racji bytu całego procesu ewaluacji. Dominujące w Polsce przekonanie o konieczności zachowania anonimowości stoi w sprzeczności z do- 
świadczeniami Brytyjczyków, którzy ograniczają anonimowość, lub całkiem ją eliminują i mają podobny stopień zwrotu ${ }^{16} \mathrm{w}$ porównaniu z naszymi uczelniami.

Znaczenie ma nie tylko anonimowość, ale także forma ankiety. Stosując w poprzednich latach wydrukowane kwestionariusze podawane studentom na ostatnich zajęciach, uzyskiwano w uczelniach polskich zwrot rzędu 90\%, a co najmniej $50 \%$ studentów uprawnionych do odpowiedzi. Dzisiaj, w dobie komputeryzacji, trudno sugerować powrót do metod papier-ołówek, niemniej ankietowanie w wersji metod drukowanych jest stosowane dziś w tych jednostkach uczelni wyższych, które decydują się angażować czas i pieniądze celem zwiększenia wiarygodności wyników ankiety. Przykładem jest Instytut Historii Sztuki Uniwersytetu Jagiellońskiego, w którym przeprowadza się badanie ankietowe w wersji papierowej po zakończeniu zajęć, ale przed sesją. To jest optymalny termin ewaluacji kształcenia, ponieważ student może się już wypowiedzieć o jakości zajęć, natomiast na jego ocenie nie ciąży jeszcze motywacja rewanżu za niską ocenę egzaminacyjną. Niezależnie od inicjatywy Instytutu studenci uczestniczą w ankiecie systemowej, obowiązującej w całej Uczelni, która jest dostępna od końca zajęć do końca sesji. Porównanie wyników ankiety jest zdecydowanie niekorzystne dla wersji elektronicznej, ponieważ w wersji papierowej mamy do czynienia ze znacznie wyższą frekwencją, a co ważniejsze, różnica pomiędzy oceną tych samych zajęć sięga 70 pkt. (w skali do stu punktów) na korzyść opinii przed sesją. Doświadczenia Instytutu Historii Sztuki UJ jednoznacznie wskazują na fakt, że ważna jest nie tylko frekwencja, ale także moment czasowy oceny. Należałoby poważnie rozważyć potrzebę oddzielenia w czasie oceny zajęć za pomocą ankiety od badania opinii o przebiegu sesji, bo jedno i drugie powinno podlegać ewaluacji. Obecnie, gdy wyniki badania jakości dydaktyki są elementem oceny pracownika uczelni, zadbanie o adekwatną ewaluację kształcenia jest kwestią uczciwości wobec nauczycieli akademickich. Chcąc uzyskać w pełni miarodajne oceny, należałoby ankietę ewaluacyjną przeprowadzić dwukrotnie, pierwszy raz bezpośrednio po zakończonych zajęciach dydaktycznych, jeszcze przed wystawieniem ocen końcowych studentom, a drugi raz po zakończeniu sesji. Prowadzenie ewaluacji zajęć dydaktycznych jedynie po sesji egzaminacyjnej może skutkować otrzymaniem błędnych ocen o prowadzących zajęcia, będących konsekwencją pobłażliwości lub surowości wobec studentów. Może skłaniać niektórych nauczycieli akademickich do stawiania lepszych stopni, celem uzyskania wyższych ocen swojej pracy. W rezultacie narzędzie służące poprawie jakości

16 Podobny, to znaczy około 30\%. Taka wartość powtarza się w raportach polskich i angielskich. 


\section{dydaktyki, jakim jest ankieta ewaluacyjna, obróci się przeciw podwyższeniu poziomu dydaktyki.}

Ze sprawą etycznego postępowania wobec pracowników dydaktycznych uczelni wiąże się też kwestia progów wiarygodności oceny, czyli ustalenia, od ilu procent zwrotu uznaje się wynik za wiarygodny. W tym zakresie uczelnie oraz instytucje przyjmują różne strategie - od braku kryteriów, to znaczy uwzględniania każdego wyniku, po stosowanie pojedynczego lub podwójnego kryterium. Pojedynczym kryterium jest procent odpowiedzi, czyli liczba otrzymanych ankiet w stosunku do liczby studentów. Drugim kryterium jest wartość bezwzględna, jaką jest suma ankiet, dotyczących określnych zajęć. Jak wcześniej wspomniano, firma Ipsos-MORI stosuje próg podwójny, a mianowicie 50\% odpowiedzi oraz liczbę co najmniej 23 odpowiadających studentów. Dobrą praktyką w niektórych uczelniach jest przystosowanie kryterium frekwencji do wielkości grupy studenckiej: im mniejsza grupa, tym wyższe kryterium.

Od kiedy wyniki ankiet są elementem oceny pracowników, pojawia się trudność związana z faktem, że niektóre zajęcia mają bardzo niski wskaźnik frekwencji. Ratunkiem w tej sytuacji wydaje się obniżanie progów wiarygodności oceny, co jest rozwiązaniem pozornym. Zazwyczaj próg ustala się odpowiednio do średniej frekwencji w uczelni czy na wydziale. Niemniej schodzenie poniżej 10\% naraża proces ewaluacji na słuszny zarzut braku wiarygodności i jest nieetyczne wobec pracownika. Równocześnie warto podkreślić, że podejmowanie negatywnych decyzji personalnych na podstawie wyników ankiet przy stopie zwrotu poniżej 50\% oceny zajęć może narazić uczelnię na porażkę w razie prawnego konfliktu z pracownikiem.

Wracając do kwestii anonimowości, jest ona powodem lekceważenia rezultatów oceny przez wielu nauczycieli akademickich, podkreślających fakt, że student może bezkarnie pisać w komentarzach i odpowiadać na ankietę, jak mu się żywnie podoba. Co gorsze, anonimowa formuła odpowiadania jest fatalna wychowawczo, ponieważ oswaja przyszłą inteligencję z pisaniem anonimów.

Problem ma znaczenie podstawowe w procesie ewaluacji dydaktyki, dlatego w artykule zwrócono szczególną uwagę na sposób, w jaki jest on rozwiązany w obu przykładowych uczelniach. Wzory te są stosowane na poziomie procedury oceny wewnątrzuczelnianej oraz zewnątrzuczelnianej.

W zakresie procedury wewnątrzuczelnianej warto rozważyć procedurę stosowaną na Uniwersytecie w Bolton, którą można określić jako anonimową, lecz kontrolowaną. Jest ona swego rodzaju wypośrodkowaniem pomiędzy anonimowością a podawaniem przez studenta pełnych danych osobowych. Aby nie powtarzać opisu, warto przypomnieć, że badanie jest anonimowe, studenci wiedzą jednak, że system zapisuje ich URL, ponieważ osoby, które zwlekają z odpowiedzią, 
otrzymują monity. Konkretna osoba z administracji uczelni, której imię i nazwisko wymienione jest w instrukcji kwestionariusza, monitoruje przebieg badania. W rezultacie, jak wcześniej wspomniano, relacja bezosobowa: student-system zostaje zamieniona na relację osobową: student-pracownik uniwersytetu. Zaufanie, konieczne w tej procedurze, opiera się właśnie na tej relacji osobowej ${ }^{17}$.

Kwestia anonimowości odpowiedzi studentów przestaje być aktualna w Wielkiej Brytanii w przypadku zewnątrzuczelnianej oceny jakości dydaktyki, prowadzonej przez niezależne od uczelni, wyspecjalizowane instytucje badania opinii publicznej, ponieważ one wszystkie pytają o dane personalne respondenta. Korzyści z udziału uczelni w tego rodzaju komparatywnej ewaluacji jest kilka. Po pierwsze, taka ocena jest z założenia jawna, bez uciekania się do anonimowości. Po drugie, uczelnia zyskuje ogromnej wagi informację o swojej pozycji w rankingu szkół wyższych, w kraju i poza granicą. Staranie się o uzyskanie dobrego miejsca jest ważnym predyktorem jakości pracy uczelni w każdym wymiarze, nie tylko dydaktycznym, i stanowi przesłankę wyboru określonej uczelni przez kandydatów, bardzo istotną na wolnym rynku usług dydaktycznych.

\section{POTENCJALNE KORZYŚCI Z ZASTOSOWANIA BRYTYJSKICH PROCEDUR EWALUACJI JAKOŚCI W WARUNKACH POLSKICH}

Podsumowując, można wypunktować korzyści wynikające z uwzględnienia sformułowanych wniosków, a mianowicie:

1. Zbudowanie narzędzia ewaluacji jakości dydaktyki, które nie podważa autorytetu nauczyciela akademickiego.

2. Złagodzenie (badania wewnętrzne) lub uniknięcie (badania zewnętrzne) konieczności prowadzenia ewaluacji jakości dydaktyki w trybie badań anonimowych.

3. Kompetentne przeprowadzenie badań ankietowych we właściwym momencie cyklu dydaktycznego, to znaczy po zakończeniu zajęć, a przed sesją egzaminacyjną, co pozwala uniknąć „błędu rewanżu” za oceny niższe niż oczekiwania studentów. Wyeliminowanie tego błędu pozwoli na zachowanie funkcji ankiety jako narzędzia służącego poprawie jakości dydaktyki, a nie jej obniżeniu.

17 Z moich doświadczeń pełnomocnika dziekana ds. ewaluacji jakości dydaktyki wynika, że student mający zaufanie do pracownika nie waha się wyrazić swojej opinii zarówno pozytywnej, jak i negatywnej w każdej istotnej dla niego sprawie. 
4. Promocja uczelni poprzez wykazanie jej rangi w porównaniu z innymi ośrodkami akademickimi w kraju i za granicą.

Czwarty postulat jest już w dużej mierze realizowany i większość polskich uczelni można znaleźć w rankingach krajowych i międzynarodowych ${ }^{18}$.

Najtrudniejszą organizacyjnie sprawą wydaje się być wprowadzenie procedur, które pozwoliłyby wyeliminować przynajmniej częściowo ciążące na studenckich ankietach brzemię anonimowości. Uruchomienie mechanizmu monitowania braku odpowiedzi oraz wyraźne skojarzenie całego procesu z konkretnym pracownikiem administracji dydaktycznej wymagałoby w dużych uczelniach, takich jak Uniwersytet Warszawski ${ }^{19}$ czy Jagielloński, powiększenia istniejących już zespołów, sekcji czy pracowni ds. ewaluacji jakości dydaktyki. Do stosowanej obecnie instrukcji dla studentów należałoby wprowadzić dwie zmiany: uprzedzić, że osoby, które nie odpowiedzą na ankietę, otrzymają monit z przypomnieniem i poinformować, kto jest odpowiedzialny za monitorowanie procesu oceny.

Rozwiązaniem o pozauczelnianym zasięgu jest udział uczelni w procesie krajowej i międzynarodowej ewaluacji jakości dydaktyki, prowadzonej przez instytucje do tego powołane. Każda wyższa uczelnia w Polsce podlega ciągłej ocenie jakości dydaktyki prowadzonej przez Państwową Komisję Akredytacyjną oraz Uczelnianą Komisję Akredytacyjną, uzyskując stosowne akredytacje na poszczególnych kierunkach, a także na poziomie wydziałów. Równocześnie uczelnie podlegają corocznemu badaniu rankingowemu, prowadzonemu przez czasopismo „Perspektywy”, w którym Uniwersytet Jagielloński zajmuje raz pierwsze, raz drugie miejsce w kraju, zamiennie z Uniwersytetem Warszawskim (Ranking szkół wyższych..., 2016). Uczelnie podlegają więc ocenie, nie ma ona jednak charakteru niezależnych badań ankietowych wśród studentów, tak jak to jest w przypadku wizytowanych uniwersytetów brytyjskich, które korzystają z abonamentu usług odpowiednich, wyspecjalizowanych firm.

Jeśli chodzi o postulat oceny jakości dydaktyki o zasięgu krajowym, należy rozważyć możliwość powołania odpowiednich organizacji, a raczej podjęcia zadań związanych z ogólnokrajową ewaluacją komparatywną, przez już działające instytucje, takie jak Ministerstwo Nauki i Szkolnictwa Wyższego czy Polska Akademia Nauk, na wzór brytyjskiej Akademii Szkolnictwa Wyższego.

18 Ranking szkół wyższych 2016 w Polsce. Perspektywy. Ranking Web of Universities (2017).

19 W roku 2015/2016 Uniwersytet Warszawski, w 200-lecie istnienia, mógł się poszczycić liczbą 51,2 tys. studentów, doktorantów i słuchaczy studiów podyplomowych. Niewiele mniejsze jest grono osób kształcących się w Uniwersytecie Jagiellońskim, które w roku akademickim 2015/2016 (652. rok istnienia) liczyło 47,5 tys. 
Kolejny postulat dotyczy włączenia uniwersytetów polskich do grupy uczelni obsługiwanych przez międzynarodowe instytucje badania opinii studentów w zakresie jakości studiowania i warunków życia. Takie usługi pełni wspomniana już The International Graduate Insight Group (i-graduate). Wiele polskich uczelni korzysta z odpowiednich metod, typu Barometr Studencki, ale o zasięgu wyłącznie uczelnianym.

Wprowadzanie zmian oraz innowacji napotyka zazwyczaj na różnego rodzaju trudności i zagrożenia.

W zakresie proponowanych zmian najtrudniejsze wydają się dwie inicjatywy, a mianowicie: po pierwsze - podjęcie działań w kierunku jawności oceny jakości dydaktyki, co może początkowo spowodować spadek frekwencji odpowiedzi, oraz po drugie - wprowadzenie uczelni polskiej na płaszczyznę oceny międzynarodowej, co może być trudne zarówno ze względu na koszty, jak i z uwagi na barierę językową; jednak ewaluacja zajęć w języku angielskim będzie stanowić dla polskich studentów z roku na rok coraz mniejszy problem.

Ocena jakości zajęć dydaktycznych jest istotnym zadaniem szkoły wyższej. Jego realizacja nadal napotyka na duże trudności, przede wszystkim w otrzymaniu wiarygodnej ilościowo i jakościowo opinii studentów, dlatego dalsze wysiłki w kierunku jej poprawy i rozwoju są społecznie uzasadnione.

\section{Bibiografia:}

National Student Survey (2017). Pobrane z: http://www.thestudentsurvey.com/.

Przewodnik po działaniach projakościowych dla pracowników Uniwersytetu Jagiellońskiego (2015). Kraków: Uczelniany Zespół ds. Jakości Kształcenia Uniwersytetu Jagiellońskiego. Pobrane z: http://www.jakosc.uj.edu.pl/documents/1609422/456c5737-21cc-4ccb-aa5f-c38b8219f392.

Quality Assurance Agency for Higher Education. Strategy 2014-17. Pobrane z: http:// www.qaa.ac.uk/en/Publications/Documents/QAA-Strategy-2014-17.pdf.

Ranking szkół wyższych 2016 w Polsce. Perspektywy. Pobrane z: http://www.perspektywy. pl/RSW2016/ranking-uczelni-akademickich.

Ranking Web of Universities. Edition 2017.2.1. July. Pobrane z: http://www.webometrics. info/en/node/178.

The International Graduate Insight Group (i-graduate). Pobrane z: http://www.tribalgroup. com/aboutus/Pages/default.aspx.

The global benchmark for the international student experience. (2017). The International Graduate Insight Group (i-graduate). Pobrane z: http://www.bartoncarlyle.com/images/ resources/ISB_Factsheet.pdf.

The Ipsos MORI Qualitative Research. Pobrane z: https://www.ipsos.com/ipsos-mori/ en-uk/qualitative-solutions. 
University of Bolton. Strategic Plan 2016-2020. Bolton: University of Bolton. Pobrane z: http://www.bolton.ac.uk/AboutUs/Resources/StrategicPlan.pdf.

University of Hertfordshire. Strategic Plan 2016-2020. Hatfield: University of Hertfordshire. Pobrane z: http://www.herts.ac.uk/_data/assets/pdf_file/0006/81969/uh-strategic-plan-2015-to-2020.pdf.

The Higher Education Academy, Pobrane z: https://www.heacademy.ac.uk/.

The Higher Education Academy (2016). Postgraduate Taught Experience Survey - PTES. Pobrane z: https://www.heacademy.ac.uk/knowledge-hub/postgraduate-taught-experience-survey-2016.

The Higher Education Academy (2017). Postgraduate Research Experience Survey - PRES. Pobrane z: https://www.heacademy.ac.uk/knowledge-hub/postgraduate-research-experience-survey-report-2017.

Student Experience Strategy 2010-2015. Hatfield: University of Hertfordshire: http:// www.studynet2.herts.ac.uk/intranet/lti.nsf/0/79CBC2FF872CF7EB80257B47004E1878/\$FILE/The\%20Student\%20Experience\%20Strategy\%202010-2015\%20with\%20 PSF\%20alignment2.pdf.

The Tribal Group PLC. Pobrane z: http://www.i-graduate.org/. 